be asked why progress has been so slow, considering that the pioneer of population dynamics was Sir Ronald Ross. In chapter five of his book, The Prevention of Malaria (London, 1910), Ross used a population model which expressed in algebraic terms the way in which infection rate was related to the properties of the human and mosquito populations, represented by six symbols. Recent developments of Ross's ideas will be found in The Epidemiology and Control of Malaria by G. MacDonald (London, 1957). This promising line is not followed here. Neither Ross nor MacDonald appears in the bibliography and no attempt is made to assess even one of Ross's six factors.

Ecologists interested in population dynamies will be disappointed in this book. Those concerned with the deployment of effort in medical entomology should consider whether the present strategy is likely to provide an understanding of these ecological problems.

G. C. VARLEY

\section{PALAEARCTIC DRAGONFLIES}

\section{Les Odonates de l'Europe Occidentale, du Nord de l'Afrique et des lles Atlantiques}

By P. Aguesse. (Faune de l'Europe et du Bassin Mediterranéen, 4.) Pp. 255. (Masson et Cie: Paris, 1968.) 80 francs.

This book is one of a series devoted to the systematics of animal taxa in the western Palaearctic Region. Publication is sponsored by the Centre Nationale de la Recherche scientifique. This volume, on dragonflies, encompasses western Europe (excluding Denmark, Poland, Romania and Yugoslavia), north-western Africa (Tunisia, Algeria and Moroceo) and Madeira, the Azores and the Canaries. Mediterranean countries east of Italy or Tunisia are not included.

The book is lavishly produced. It contains four beautiful colour plates and a half-tone sketch by the noted illustrator and naturalist P.-A. Robert.

The text is arranged in two parts: general and systematic. The first deals with the morphology and bionomics of dragonflies as a group. It presents, in 67 pages, a selection of published information, and includes some unpublished findings known to the author. Matorial is not critically reported; terminology is not always consistent; authors are sometimes misquoted; and the source of a specific fact can seldom be traced unequivocally. To some readers the most interesting part of this general section will be that devoted to seasonal regulation because of the detailed treatment given to little-known work by Schaller and the author on dimorphic growth rate in Aeshnidae. These findings are likely to have considerable influence on future work in this field. Here as elsewhere, however, the author's treatment of his subject fails to be authoritative because other relevant studies (for example, those by Lutz and Jenner) are omitted and their implications are not taken into account.

The second, systematic part, occupying about two thirds of the book, contains separate sections on adults and larvae. It combines taxonomic information for European species, which are well known, with that for the north-western African species. This part is adequate and useful, although some pertinent references are omitted. Keys and accompanying illustrations by the author are clear, and easy to find and use. Distribution maps are given for some species.

There is a bibliography of some 300 titles and an index to the 40 genera and 109 species treated. The value of the extensive bibliography is reduced by the omission of certain key references (including several cited in the text), and by the fact that many entries lack page numbers. Mention of a reference in the bibliography does not mean that its contents have been eited, or allowed for, in the text.

People requiring a manual, in one cover, for western Palaearctic Odonata will find the systematic part of this book useful. Philit S. Corbet

\section{LYMPHOCYTE STIMULATION}

\section{Lymphocyte Stimulation}

By N. R. Ling. Pp. 290. (North Holland: Amsterdam, 1968.) $117 s$.

IT is perhaps hardly surprising that many experimental observations are neglected until their real significance can be evaluated against an appropriate backcloth. Such was the case with immunological tolerance, the consequences of which were known to experimental embryologists long before its existence as an important biological phenomenon had been demonstrated; and, as Dr Ling points out in his scholarly book, the same could be said of lymphocyte stimulation. Thus Maximow at the turn of the century described the occurrence of blast cells in inflammatory exudates and he contended that at least some of them were derived from blood lymphocytes, and with the benefit of hindsight it is clear that Bloom's later descriptions of cell transformations referred to the development of blast cells from lymphocytes.

It was, however, the discovery in the middle fifties of the plant agglutinins (or lectins)-notable among them those of the red kidney bean Phaseolus vulgaris-and the realization that lymphocytes play a vital part in graft rejection and in delayed hypersensitivity that set the stage for carefully conducted and controlled in vitro experiments on lymphocyte stimulation. Among the morphological and biochemical changes that occur when lymphocytes are cultured in the presence of phytohaem. agglutinins (PHA) or other stimuli are cell and nuclear enlargement, the development of an ample cytoplasm, the appearance of numerous free ribosomes, greater pinocytotic activity, increased RNA and subsequently DNA synthesis, and finally cell division. Ling is undoubtedly justified in giving pride of place to PHA, which has been used so extensively in the study of lymphocyte stimulation, but sections of the book are also devoted to the stimulatory effects of tuberculin products, staphylococcal filtrate, smallpox vaccine, heterologous antibodies and cell contact. Perhaps least satisfactory is his treatment of allogeneic inhibition which, although it is concerned with cytotoxicity, deserves closer scrutiny in the context of lymphocyte stimulation.

Ling makes the reader fully aware of the complex technology that has been applied to the study of lymphocytes, and his chapter on lymphocyte culture will be most valuable to those embarking on work or already working in this field. What also emerges is that in many respects we are still remarkably ignorant of the immunological status of cells stimulated in vitro; the literature on the presence of specific immunoglobulins is still somewhat confused, and it would seem that little is known about the immunological performance of stimulated lymphocytes. On the question of how stimulation comes about there is room for argument too, but Ling favours the presence of specific cellular receptors which bind the stimulant rather than agglutination per se, or nutritional factors, or micro-injury. If this is so, lymphocyte stimulation, which in any one culture occurs in a high proportion of cells, would not be easy to square with the clonal selection hypothesis.

This timely book, which is written with great lucidity, will be most welcome to those working in the field. But because it encompasses so many facets of the subjectbiological, biochemical, immunological and clinical-its appeal will be not only to those interested in lymphocytes but to cell biologists of every hue. LesLie Brent 